\title{
In Vitro Digestibilities of Plants in Rumen Fluids of Peary Caribou
}

\author{
DONALD C. THOMAS ${ }^{1}$ and PETER KROEGER'
}

\begin{abstract}
In vitro fermentation with expressed rumen fluids was used to evaluate the apparent comparative digestibilities of plants ingested by Peary caribou (Rangifer tarandus pearyi) in arctic Canada. The apparent digestibilities of vascular plant components collected in summer and fermented for 60 hours with "summer" rumen inoculum generally were in the range $50-80 \%$, digestibilities of lichens ranged from $18-85 \%$, and those of mosses from 11-35\%. In similar trials in which plants collected in the winter were fermented for 60 hours with "winter" rumen inoculum, the green parts of two sedge species were more digestible ( 65 and $74 \%$ ) than the corresponding cured leaves ( 25 and $43 \%$ ), lichens generally were highly digestible (54-83\%), and mosses poorly digested (3-11\%). We obtained clear evidence of a seasonal change in the digestive capacity of rumen fluids. Fermentation for periods of 30,60 , and 90 hours revealed that components of vascular plants were digested most rapidly, followed by lichens and mosses. There was no interaction among mixed samples of plants; composite digestibilities approximated expected values based on weighted mean digestibilities of the component species. Peary caribou select forages of high digestibility but they consume, perhaps incidentally, plants of low digestibility when snow or ice restricts their access to the highly digestible species.
\end{abstract}

Key words: caribou, in vitro, microdigestion, arctic plants, rumen, rangifer

RÉSUMÉ. La fermentation "in vitro" dans des liquides extraits de la panse fut utilisée afin d'évaluer la digestibilité relative ainsi observée des plantes ingérées par le caribou Peary (Rangifer tarandus pearyi) dans l'Arctique canadien. Des plantes vasculaires recueillies en été et fermentées durant 60 heures dans du liquide de panse "d'été" ont été digestibles généralement dans une proportion variant entre $50-80 \%$; entre $18-85 \%$ pour les lichens; et $11-35 \%$ pour les mousses. Dans des essais semblables utilisant des plantes recueillies en hiver et fermentées durant 60 heures dans du liquide de panse " $d$ 'hiver", il est apparu que les éléments verts de deux espèces de carex étaient plus digestibles (65 et $74 \%$ ) que leur feuillage séché correspondant ( 25 et $43 \%$ ); que les lichens l'etaient en général hautement (54-83\%); et que les mousses étaient peu digérées (3-11\%). Nous avons obtenu des indications claires d'un changement saisonnier dans la capacité digestive des liquides contenus dans la panse. Une fermentation pour des périodes de 30,60 et 90 heures a montré que les plantes vasculaires étaient les plus digestibles, suivies des lichens et des mousses. Des essais sur des mélanges de plantes ne révélèrent aucune interaction: les valeurs de digestibilité obtenues pour ces mélanges se rapprochent de celles auxquelles on s'attendait en se basant sur les moyennes pondérées pour les espèces constituantes. Le caribou Peary choisit les fourrages hautement digestibles, mais il consomme à l'occasion des plantes à faible coefficient quand la neige ou la glace restreignent l'accès aux espèces plus facilement digestibles.

Traduit par Ian Badgley, Université du Québec à Montréal.

\section{INTRODUCTION}

Recent data on the diets of Peary caribou indicate considerable regional and seasonal variability. They also revealed high proportions of mosses in the rumens and fecal material of Peary caribou, especially in those whose access to forage was impeded by deep snow or ice (Fischer and Duncan, 1975; Parker $e t$ al., 1975; Parker, 1978; Shank et al., 1978; Thomas et al., 1976; 1977; Thomas and Broughton, 1978). Once diet is known, the next step is to ascertain the digestibili- 
ties of plants consumed. There are no such data for Peary caribou and few data for other Rangifer. Many researchers make the jump from data on available forage and the composition of plant fragments in rumens and feces to the chemical composition and energy of forages. In doing so, they bypass at least four Walesconsiderations: composition of ingesta, degree of digestion, rate of digestion, and passage time in the alimentary canal. Our objective was to use in vitro dry-matter disappearance (IVDMD) techniques to help clarify the relative digestibilities of various plant species in Peary caribou and to investigate possible interactions between two or more forages digested together.

The IVDMD technique is a proven means of evaluating the comparative digestibilities of forages (Johnson, 1966.) It can be used to estimate digestibilities after finding the relationship between IVDMD and nylon-bag digestibilities, the latter supposedly approximating in vivo digestibilities. Person et al. (1980), in studies on captive reindeer ( $R$. $t$. sibericus $=$ tarandus $)$, found that, relative to nylon-bag digestibilities, the in vitro estimates were 46-70\% lower for six shrubs, 5-82\% lower for 13 lichens, and unpredictable (five higher, three lower) for grasses and sedges, and for mosses (two higher, one lower). They attributed the relatively low in vitro digestibilities to nitrogen deficiencies and to the inhibitory effects of toxic substances in the lichens and shrubs.

Our research was spurred by speculation on the importance of mosses in the diets of Peary caribou. We suggested that they are of little consequence as forage because of assumed low digestibilities (Thomas et al., 1976, 1977). However, some species of moss may provide significant sources of energy in winters in which access to more nutritious forage is highly restricted by snow and ice. Rumen fluids taken from caribou shot on their natural range may provide better data on the comparative digestibilities of a wide range of forages, including mosses, than fluids from captive animals fed artificial or simulated diets.

\section{METHODS}

We established a temporary laboratory in Resolute Bay, Northwest Territories, to which plant samples and freshly-killed caribou were transported by aircraft. In the summer of 1978, we collected plant samples on Cornwallis, Little Cornwallis, Prince of Wales, and Somerset islands, and retained voucher specimens for identification. In March 1979, we collected plants from the feeding sites of caribou on Somerset and Prince of Wales islands. Old and necrotic lichen and moss tissues were excluded from the samples, and only the terminal green stems of Salix arctica were obtained. Samples were dried at $55^{\circ} \mathrm{C}$, ground twice in a Wiley Mill (no. 20 screen), and further dried at $55^{\circ} \mathrm{C}$. After 1-2 days of drying, we measured $0.5 \mathrm{~g}$ samples into $25 \times 200 \mathrm{~mm}(75 \mathrm{ml})$ test tubes and followed Procedure D of Tilley and Terry (1963), except that the first stage of digestion (fermentation) was extended to 60 hours for most of the trials. Duplicates of a few samples were fermented in $125 \mathrm{ml}$ Erlenmeyer flasks for comparative purposes.

The source of inoculum in the summer of 1978 was pooled rumen fluids from five male caribou obtained on 7 August on Prince of Wales Island. Winter 
inoculum came from four adult females and one yearling male obtained on 7 April 1979 on the same island. Only three to four hours elapsed between death and the removal of rumens from the intact animals; cooling was negligible because we handled the rumen contents in a room heated to $40^{\circ} \mathrm{C}$ (summer) and $30^{\circ} \mathrm{C}$ (winter). Fluids were obtained by manually squeezing 0.51 batches of rumen contents within four layers of cheesecloth. Anaerobic conditions were maintained by periodic infusion of carbon dioxide gas. We found it necessary to add 2.2N HCl slowly to the tubes containing McDougall's buffer and in $4 \times 1 \mathrm{ml}$ aliquots, then $2 \times 2 \mathrm{ml}$ lots. Otherwise, gas production was too rapid.

In this paper the terms digestion, digestibility, and dry-matter disappearance (DMD) are all expressed as percentages and are used interchangeably. Where digestion or digestibility is used it is understood that those terms are more correctly prefaced with "apparent" and all the qualifications that it implies (Johnson, 1966) when using the IVDMD technique without comparative data from nylon-bag digestibilities. To facilitate discussion of the results we arbitrarily classified digestibilities as very low, low, moderate, high, and very high, in equal $20 \%$ steps.

\section{RESULTS}

\section{a) The Relative Digestibilities of Plant Species}

Summer Vegetation and Inoculum (Tables 1, 2): Only Puccinellia spp. and Alectoria ochroleuca were very highly (81-100\%) digestible. In the high (61-80\%) digestibility group were leaves and inflorescences of Salix arctica and Alopecurus alpinus, inflorescences of Saxifraga oppositifolia and Papaver radicatum, green leaves of Eriophorum triste, and the lichens Cetraria cucullata, $C$. islandica, C. delisei and Dactylina arctica. Of moderate (41-60\%) digestibility were Salix arctica stems, leaves of Dryas integrifolia and Cassiope tetragona, Carex stans, C. misandra, Eriophorum Scheuchzeri, green parts of Luzula spp., and the lichens $C$. tilesii and Alectoria pubescens. The low (21-40\%) digestibility group included $S$. oppositifolia leaves, dead leaves of Luzula spp., Cladina mitis, and four moss samples each composed of one to three species. In our very low (1-20\%) digestibility category we found Thamnolia vermicularis and six samples of mosses, some of mixed species.

The apparent digestibility of all recent growth of Salix arctica was relatively high (58-68\%). The IVDMD of Dryas integrifolia leaves was relatively high (53\%) considering that the samples contained leaves from several seasons. The IVDMD of inflorescences of Saxifraga oppositifolia (73\%) was double that of the leaves. In general, IVDMDs of inflorescences of the species tested were high (65-79\%); all are known to be utilized or selected by Peary caribou in summer.

As found in Rangifer in Alaska (Person et al., 1975), the IVDMDs of grasses were higher than those of sedges, except for Eriophorum triste. The sample of $E$. Scheuchzeri was derived largely from stems, which may account for its low digestibility (59\%) relative to those of other species of grasses and sedges. In contrast, the Puccinellia spp. sample was derived entirely from broad, green, tender leaves. The relatively low digestibility of Carex stans (53\%) was note- 
Table 1. Apparent digestibilities (\%) of plant species collected in summer and fermented for $60 \mathrm{~h}$ in vitro with rumen fluids from caribou collected in summer

\begin{tabular}{|c|c|c|c|}
\hline \multirow{2}{*}{ Plant species } & \multicolumn{3}{|c|}{ Dry-matter disappearance $(\%)$} \\
\hline & Tube 1 & Tube 2 & Mean \pm SD \\
\hline \multicolumn{4}{|l|}{ Shrubs \& shrub-like } \\
\hline Salix arctica, leaves & 69.2 & 66.9 & $68.1 \pm 1.6$ \\
\hline stems & 56.9 & 58.8 & $57.9 \pm 1.3$ \\
\hline inflorescences & 64.6 & & \\
\hline Dryas integrifolia, leaves & 57.4 & 48.8. & $53.1 \pm 6.1$ \\
\hline Cassiope tetragona, leaves & 50.8 & 49.5 & $50.2 \pm 0.9$ \\
\hline Saxifraga oppositifolia, leaves & 35.4 & 37.2 & $36.3 \pm 1.3$ \\
\hline inflorescences & 73.4 & & \\
\hline \multicolumn{4}{|l|}{ Monocotyledons } \\
\hline Carex stans, green leaves & 53.5 & 52.5 & $53.0 \pm 0.7$ \\
\hline C. misandra, green leaves & 46.0 & & \\
\hline Eriophorum triste, green leaves & 74.8 & & \\
\hline E. Scheuchzeri, green leaves and stems & 59.1 & & \\
\hline Luzula spp., green leaves, stems & 52.3 & 59.4 & $55.9 \pm 5.0$ \\
\hline dead leaves & 27.9 & & \\
\hline Alopecurus alpinus, green leaves, stems & 71.0 & & \\
\hline inflorescences & 73.9 & & \\
\hline Puccinellia spp., green leaves & 81.5 & & \\
\hline \multicolumn{4}{|l|}{ Forb } \\
\hline Papaver radicatum, flowers & 78.8 & & \\
\hline \multicolumn{4}{|l|}{ Lichens } \\
\hline Cetraria cucullata & 76.5 & 75.0 & $75.8 \pm 1.1$ \\
\hline C. islandica & 75.5 & & \\
\hline C. delisei & 61.8 & & \\
\hline C. tilesii & 44.8 & & \\
\hline Alectoria ochroleuca & 84.8 & & \\
\hline A. pubescens & 53.6 & & \\
\hline Dactylina arctica & 71.5 & & \\
\hline Cladina mitis & 30.5 & & \\
\hline Thamnolia vermicularis & 18.5 & 17.1 & $17.8 \pm 1.0$ \\
\hline
\end{tabular}

worthy because the leaves appeared to be more succulent than those of Luzula spp. (56\%), rushes that we grouped with sedges. The digestibility of the dried leaves of Luzula spp. (28\%) was only half that of the green leaves and shoots.

The large range of values for lichens, $18-85 \%$, may be more a function of prior utilization and subsequent proliferation of specialized rumen microorganisms (bacteria and ciliates) than of structural or chemical differences among the lichen species. The IVDMD values for mosses (Table 2 ) were comparable to the results obtained in Alaska (Person et al., 1980).

Winter Vegetation and Inoculum (Tables 3, 4): The following results are based on 60 hours of fermentation to facilitate comparisons with data in the previous section. Very high digestibilities characterized Alectoria ochroleuca and A. nigricans. Our arbitrary class termed high digestibility included green parts of Carex 
Table 2. Apparent digestibilities (\%) of moss species collected in summer and fermented for $60 \mathrm{~h}$ in vitro with rumen fluids from caribou collected in summer

\begin{tabular}{lrrr}
\hline \hline \multirow{2}{*}{ Moss species } & \multicolumn{3}{c}{ Dry-matter disappearance (\%) } \\
\cline { 2 - 3 } & Tube 1 & Tube 2 & Mean \pm SD \\
\hline Rhacomitrium lanuginosum & & 12.8 & $10.6 \pm 3.2$ \\
Tomenthypnum nitens & 19.5 & & \\
T. nitens (sample 2) & 16.0 & & \\
Didymodon asperifolius & 23.0 & \\
Bryum cryophilum \& Philonotis fontana & 35.4 & \\
P. fontana, Orthothecium chryseum \& Bryum spp. & 29.0 & \\
Timmia austriaca, Ditrichum flexicaule & & \\
$\quad$ \& Aulacomnium turgidum & 23.3 & \\
Aulacomnium acuminatum \& A. turgidum & 13.2 & \\
Tortula ruralis, Hypnum procerrimum, Myurella & & \\
$\quad$ julacea, D. asperifolius \& D. flexicaule & 16.0 & \\
Unidentified & 13.6 & \\
\end{tabular}

Table 3. Apparent digestibilities ( $\overline{\mathrm{x}} \%, \pm \mathrm{SD}$ for duplicates) of plant species collected in winter and fermented at three intervals with rumen fluids obtained from caribou shot in the winter

\begin{tabular}{lrcc}
\hline \hline & \multicolumn{3}{c}{ Fermentation period (h) } \\
\cline { 2 - 4 } Plant species & \multicolumn{1}{c}{30} & 60 & 90 \\
\hline Salix arctica, green stems <3 mm dia & 52.5 & $49.3 \pm 7.8$ & 54.2 \\
Cassiope tetragona, green leaves & 43.5 & $49.1 \pm 6.8$ & 45.2 \\
Saxifraga oppositifolia, leaves & 10.3 & $14.7 \pm 2.7$ & 10.7 \\
Dryas integrifolia, leaves & 6.8 & $16.6 \pm 2.0$ & 21.6 \\
Carex stans, cured leaves & 36.6 & $42.9 \pm 3.2$ & 44.6 \\
C. stans, green leaves, stems & 78.9 & $74.2 \pm 3.8$ & 77.2 \\
C. misandra, cured leaves & 25.1 & $25.2 \pm 0.6$ & 31.0 \\
C. misandra, green leaves & 62.4 & $65.4 \pm 3.0$ & 69.0 \\
Cetraria cucullata & 69.2 & $73.7 \pm 4.0^{1}$ & 80.1 \\
C. nivalis & 50.2 & $74.3 \pm 1.0$ & 77.9 \\
C. islandica & & $69.4 \pm 0.1$ & \\
C. delisei & 46.2 & $60.7 \pm 2.8$ & 61.2 \\
Thamnolia vermicularis & & $62.0 \pm 6.6$ & \\
Dactylina madreporiformis & & $54.3 \pm 5.0$ & \\
D. arctica & & 63.2 & \\
Alectoria ochroleuca & 74.7 & $83.3 \pm 3.7$ & 84.0 \\
A. nigricans & & 81.1 & \\
\hline
\end{tabular}

'Three tubes

stans and C. misandra as well as Cetraria cucullata, $C$. nivalis, $C$. islandica, C.delisei, Thamnolia vermicularis, and Dactylina arctica. Moderately digestible were Salix arctica (green stems), Cassiope tetragona, and cured leaves of Carex stans. Cured leaves of $C$. misandra were of low digestibility, whereas leaves of Saxifraga oppositifolia and Dryas integrifolia and all mosses fell into our very low digestibility category. 
Table 4. Apparent digestibilities ( $\overline{\mathrm{x}} \%, \pm$ SD for duplicates) of moss species collected in winter and fermented at three intervals with rumen fluids obtained from caribou shot in the winter

\begin{tabular}{lccc}
\hline \hline Moss species & \multicolumn{3}{c}{ Fermentation time (h) } \\
\cline { 2 - 4 } & 30 & 60 & 90 \\
\hline Rhacomitrium lanuginosum & 6.7 & $5.9 \pm 1.8$ & 6.6 \\
R. lanuginosum (sample 2) & 1.2 & $2.5 \pm 2.0$ & 5.0 \\
R. lanuginosum (sample 3) & & $3.8 \pm 0.4$ & \\
R. lanuginosum (sample 4) & & 8.7 & \\
R. lanuginosum (sample 5) & & 4.5 & \\
Drepanocladus revolvens & 10.4 & $10.2 \pm 2.4$ & \\
Ditrichum flexicaule & & & \\
Dicranum elongatum, Ditrichum flexicaule & & 4.8 & \\
$\quad$ \& Anastrophyllum minutum & & & \\
D. flexicaule, Hypnum bambergeri, Tomenthypnum & & & \\
$\quad$ nitens, Cinclidium arcticum \& Distichium & & $11.4 \pm 0.2$ & \\
$\quad$ capillaceum & & & \\
\end{tabular}

b) Seasonal Changes In Digestibility (Tables 1, 3)

Seasonal changes in the plants or the rumen inoculum or both could account for within-species differences in digestibilities between summer and winter tests. Digestibility of the leaves of Dryas integrifolia decreased from $53 \%$ in summer to $17 \%$ in winter; those of Saxifraga oppositifolia from $36 \%$ to $15 \%$. We attribute those differences to maturation of the leaves and the presence in the winter sample of leaves from more than one year. In contrast, the digestibilities of green parts of Carex stans increased from 53\% in summer to $74 \%$ in winter; those of $C$. misandra from $46 \%$ in summer to $65 \%$ in winter. Those changes may be caused by sample differences but more likely they reflect changes in rumen function. The apparent digestibility of Thamnolia vermicularis increased from $18 \%$ in summer to $62 \%$ in winter. Changes from summer to winter in seven other species were all less than $9 \%$, although the winter values were lower in all cases.

c) Effect Of Fermentation Time On Apparent Digestion (Tables 3, 4)

Digestion of all the vascular species that we tested, with the exception of Dryas integrifolia, was maximal or nearly so after 30 hours of fermentation with winter inoculum. IVDMD of the lichen species tested generally increased with increasing fermentation time but digestion was essentially complete after $\mathbf{6 0}$ hours. Digestion of two of three moss species increased with longer fermentation times. The trend established by the available samples was that vascular plant species were digested most rapidly, followed by lichen species, and then mosses.

\section{d) Changes in The Digestive Capacities Of Rumen Fluids From Summer To Winter}

We investigated seasonal changes in the digestive capacities of inocula by holding the forage component constant, i.e., we compared the results of the summer and winter trials on subsamples of the same ground samples of vegetation obtained in the summer. The comparison was summer plants and summer 
Table 5. Apparent digestibilities (\%) of plant species collected in the summer and fermented for $60 \mathrm{~h}$ in vitro with rumen fluids obtained from caribou shot in summer and winter

\begin{tabular}{|c|c|c|c|}
\hline \multirow[b]{2}{*}{ Species collected in summer } & \multicolumn{2}{|c|}{ Digestibility $(\tilde{x} \pm \mathrm{SD})$} & \multirow{2}{*}{$\begin{array}{c}\text { Change, } \\
\text { summer to } \\
\text { winter (\%) }\end{array}$} \\
\hline & $\begin{array}{c}\text { Summer } \\
\text { fluids }{ }^{1}\end{array}$ & $\begin{array}{c}\text { Winter } \\
\text { fluids } \\
\end{array}$ & \\
\hline Salix arctica, leaves & $68.1 \pm 1.6$ & $65.5 \pm 1.1$ & $-\quad 3.8$ \\
\hline Cassiope tetragona, leaves & $50.2 \pm 0.9$ & $45.3 \pm 5.2$ & -9.8 \\
\hline Eriophorum Scheuchzeri, leaves \& stems & 59.1 & $71.6 \pm 1.8$ & 21.2 \\
\hline Cetraria cucullata & $75.8 \pm 1.1$ & $75.7 \pm 0.4$ & -0.1 \\
\hline C. delisei & 61.8 & $81.2 \pm 2.7$ & 31.4 \\
\hline Alectoria ochroleuca & 84.8 & $88.4 \pm 1.6$ & 4.2 \\
\hline Thamnolia vermicularis & $17.8 \pm 1.0$ & $56.8 \pm 0.3$ & 219.1 \\
\hline Didymodon asperifolius & 23.0 & $14.5 \pm 1.2$ & -37.0 \\
\hline Bryum cryophilum \& Philonotis fontana & 35.4 & 29.0 & -18.1 \\
\hline
\end{tabular}

'data from Table 1

Table 6. Apparent digestibilities ( $\overline{\mathrm{x}} \% \pm \mathrm{SD}$ ) of plant species collected at different locations in summer and winter and fermented for $60 \mathrm{~h}$ in vitro with rumen fluids obtained from caribou shot in the winter

\begin{tabular}{lccc}
\hline \hline Plant species & \multicolumn{2}{c}{$\begin{array}{c}\text { IVDMD (\%) in winter rumen } \\
\text { fluids of plants collected: }\end{array}$} & $\begin{array}{c}\text { Change (\%) } \\
\text { from summer } \\
\text { to winter }\end{array}$ \\
\cline { 2 - 4 } & In summer ${ }^{1}$ & In winter ${ }^{2}$ & \\
Cassiope tetragona, leaves & $45.3 \pm 5.2$ & $49.1 \pm 6.8$ & 8.4 \\
Cetraria cucullata & $75.7 \pm 0.4$ & $73.7 \pm 4.0$ & -2.6 \\
C. delisei & $81.2 \pm 2.7$ & $60.7 \pm 2.8$ & -25.2 \\
Alectoria ochroleuca & $88.4 \pm 1.6$ & $83.3 \pm 3.7$ & -5.8 \\
Thamnolia vermicularis & $56.8 \pm 0.3$ & $62.0 \pm 6.6$ & 9.2 \\
\hline
\end{tabular}

1 data from Table 5

${ }^{2}$ data from Table 3

inoculum vs. summer plants and winter inoculum. The summer samples were stored from August to April in a ground and dried state. Changes from summer to winter in the digestive capacities of inocula were small and unpredictable for vascular species, negligible to large increases for lichens, and decreases for mosses (Table 5). We attribute the $219 \%$ increase from summer to winter in the digestibility of Thamnolia vermicularis to seasonal differences in intake with concomitant changes in ruminal microflora.

\section{e) Effect Of Season Of Vegetation Collection On Digestion}

We investigated seasonal changes in the digestibilities of slow-growing species by comparing IVDMDs of four lichen species and Cassiope tetragona which we collected in summer and in winter and fermented for 60 hours with winter inoculum. The comparisons were summer plants and winter inoculum $v s$. winter 
Table 7. Observed digestibilities of mixed samples of plant species obtained in winter and fermented for $60 \mathrm{~h}$ in vitro with rumen fluids obtained from caribou in winter, and expected values based on proportions (parentheses) and apparent digestibilities (Table 2) of each species

\begin{tabular}{|c|c|c|}
\hline \multirow[b]{2}{*}{ Plant species and proportions (\%) of each } & \multicolumn{2}{|c|}{ Apparent digestibilities (\%) } \\
\hline & Expected & Observed $(\overline{\mathrm{x}} \pm \mathrm{SD})$ \\
\hline Salix arctica stems (50.2) and Carex misandra, cured (49.8) & 37.3 & 39.5 \\
\hline \multicolumn{3}{|l|}{ S. arctica stems (33.5), C. misandra (33.3) and } \\
\hline Rhacomitrium lanuginosum ${ }^{1}$ (33.2) & 27.0 & 30.2 \\
\hline Saxifraga oppositifolia (50.0) and Cetraria delisei (50.0) & 37.7 & $39.2 \pm 1.6$ \\
\hline \multicolumn{3}{|l|}{ S. oppositifolia (33.8), C. delisei (33.1) } \\
\hline and $R$. lanuginosum ${ }^{1}(33.1)$ & 27.0 & $25.0 \pm 1.3$ \\
\hline Carex misandra, green (50.0) and Cetraria cucullata $(50.0)$ & 68.8 & $66.6 \pm 2.8$ \\
\hline \multicolumn{3}{|l|}{ C. misandra, green (32.9), C. cucullata (33.2) } \\
\hline and $R$. lanuginosum ${ }^{1}(33.9)$ & 47.5 & $47.8 \pm 2.1$ \\
\hline C. misandra, green (50.0) and C. misandra, cured (50.0) & 45.3 & $46.0 \pm 0.5$ \\
\hline Carex stans, green (50.5) and C. stans, cured (49.5) & 58.0 & $60.7 \pm 4.7$ \\
\hline
\end{tabular}

'Sample 1

Table 8. A comparison of apparent digestibilities $(\overline{\mathrm{x}} \pm \mathrm{SD})$ of plant species fermented for $60 \mathrm{~h}$ in vitro in $75 \mathrm{ml}$ test tubes and in $125 \mathrm{ml}$ Erlenmeyer flasks with rumen fluids obtained from caribou in winter

\begin{tabular}{|c|c|c|c|}
\hline \multirow{2}{*}{$\begin{array}{l}\text { Plant species obtained } \\
\text { in winter }\end{array}$} & \multicolumn{2}{|c|}{ Digestibility $(\bar{x} \pm$ SD) in: } & \multirow{2}{*}{$\begin{array}{l}\text { \% deviation of } \\
\text { flasks from tubes }\end{array}$} \\
\hline & Tubes 1 & Flasks & \\
\hline Salix arctica, green stems & $49.3 \pm 7.8$ & $47.5 \pm 2.1$ & -3.7 \\
\hline Saxifraga oppositifolia, leaves & $14.7 \pm 2.7$ & $21.6 \pm 0.6$ & 46.9 \\
\hline Carex stans, cured leaves & $42.9 \pm 3.2$ & $42.3 \pm 2.5$ & -1.3 \\
\hline Cetraria cucullata & $73.7 \pm 4.0$ & $77.8 \pm 2.1$ & 5.6 \\
\hline C. nivalis & $74.3 \pm 1.0$ & $88.1 \pm 1.6$ & 18.6 \\
\hline C. delisei & $60.7 \pm 2.8$ & $65.5 \pm 2.1$ & 7.9 \\
\hline Alectoria ochroleuca & $83.3 \pm 3.7$ & $88.7 \pm 1.1$ & 6.5 \\
\hline
\end{tabular}

${ }^{1}$ data from Table 3

plants and winter inoculum. There were insignificant seasonal differences in the digestibilities of the five plant species tested with the exception of Cetraria deisei (Table 6). Some differences between samples are expected, although species that differ little in their overt structure from summer to winter were selected for this test. Similar tests in the future should be done on samples from the same site to preclude the possibility of geographic variation in the digestibilities of plants, as found in Alaska by Person et al. (1980).

\section{f) Effect Of Mixing Species On The Composite Digestibility}

There was no evidence of any inhibitory or complementary effects of one plant species on another in IVDMD trials on mixed samples (Table 7). Observed, 
composite, digestibility values (weighted) were exceedingly close to expected values $\left(\mathbf{P}<0.001, \alpha^{2}\right)$.

\section{g) Effect Of Type Of Fermentation Vessel On Apparent Digestion}

Fermentation of aliquots of the same milled samples in Erlenmeyer flasks and in test tubes resulted in higher digestibilities in the former for five of seven species tested, with large differences in two (Table 8). The largest difference (47\%) was for Saxifraga oppositifolia, a species of very low digestibility in tubes (15\%). We believe that digestion, on average, is higher in flasks than in tubes because of better contact between the inoculum and the substrate. Gas production gradually caused some of the plant material in test tubes to rise out of the inoculum-buffer medium, necessitating periodic shake downs. Erlenmeyer flasks have two major disadvantages: they take up considerable space in the ovens and filtration of their contents is difficult for some unknown reason.

\section{h) Reliability Of Single Values}

An index to the reliability of non-replicated values was obtained by examining the average of all the standard deviations (SDs) of means where duplicates or triplicates were obtained. The means of the SDs in the summer and the winter trials were $2.22(\mathrm{~N}=10)$ and $2.63(\mathrm{~N}=35)$, respectively, and they appeared to be independent of the size of the IVDMD values. These statistics suggest that $95 \%$ of $n$ replicated values in the summer and winter trials would be within 5.0 and 5.4 units, respectively, of the single values.

\section{DISCUSSION}

Our IVDMD values for shrubs and lichens are closer to the nylon-bag digestibilities obtained by Person et al . (1980) than to their in vitro estimates. Their low IVDMD values cannot be explained entirely by their shorter fermentation time (48 hours). Our data generally showed increasing IVDMD with longer fermentation times for lichens. As a percentage of the 90 hour fermentation values, the 30 hour and 60 hour (parentheses) values for the four lichen species were 86.4 (92.0), 64.4 (95.4), $75.5(99.2)$, and 88.9 (99.2). Therefore, the low values for lichens obtained by Person et al. (1975) were caused by other factors, such as techniques of obtaining inocula and the dietary history of donor animals. The only reported major differences between our in vitro technique and theirs was in the method of obtaining rumen fluids and their centrifugation of the tubes between the two stages of digestion.

Trudell et al. (1979) suggested that the ranking of Rangifer forages from IVDMD data may produce errors because of 1) variable inoculum sources, 2) nitrogen limitations, 3) the possible buildup of fermentation end products, and 4) fermentation inhibitors. Their results indicated higher IVDMD values for a given forage if it was in the diets of inoculum donors than if it was not ingested prior to obtaining inoculum. Our data on winter and summer IVDMDs of Thamnolia vermicularis and some other lichen species, using aliquots of the same dried sample obtained in summer, indicate the importance of inoculum sources. Tests 
should, therefore, only be made on forages known to be consumed by inoculum donors.

Our high IVDMD values for many lichen species, compared with the Alaskan results (Person et al., 1975; 1980), suggest that nitrogen was not a serious limiting factor in our closed in vitro system, as it apparently was in theirs. Trudell et al. (1979) and White and Jacobsen (unpubl. in Person et al., 1980) raised the IVDMD of mixed lichens $17-18 \%$ by adding a nitrogen source (urea) to their fermentation flasks. We observed that caribou selected the central winter-green leaves and stems of sedges in winter. Those green parts undoubtedly have a relatively high nitrogen content compared with the dried leaves. The oven-dry weight of green parts constituted $12.5 \%$ of the above-ground biomass in a sample of five plants of Carex misandra. The comparable value for $C$. stans would be higher.

We are unable to assess the third and fourth sources of possible error enumerated by Trudell et al. (1979), except to note that no interactions among the mixed plant species were found. Person et al. (1980) also found no interactions among mixed samples, a remarkable result if nitrogen limits IVDMDs of components. Fermentation inhibitors apparently affected IVDMD values of shrubs and lichens fermented with Rangifer inocula (Trudell et al., 1979). Milchunas et al. (1978) found significant positive in vitro associate effects among mixed mule deer (Odocoileus hemionus) forages but they cited three other researchers who found none.

In many studies there was acceptable agreement betwen IVDMD and nylonbag estimates of forage digestibilities, with the former tending to give slightly lower values. For example, Urness et al. (1977), in their studies on mule deer, obtained a correlation coefficient (r) of 0.84 despite some large differences between techniques for plant species with IVDMD values below 35\%. Milchunas et al. (1978), using data from several sources, suggested that nylon-bag DMD could be calculated from IVDMD values for deer with the regression equation $\mathrm{y}=1.377+0.935 x$, for which $\mathrm{r}=0.97$.

Data on the seasonal diets of Peary caribou (previously cited) and our observations in the field, combined with these results, reveal that the subspecies selects forages of high digestibility, if available. As snow or ice increasingly restrict forage supply there are increasing proportions of plant species of low or very low digestibility in the rumens (Thomas et al., 1976; 1977). Such species, because of slow passage through the rumen, may be overrepresented there relative to their proportionate intake. Peary caribou seemingly attempt to fill their rumens with whatever vegetation is available when snow or ice restricts access to the highly digestible species.

The present data on diets of Peary caribou and on forage digestibilities enable us to assess ranges and understand some of the energy limitations imposed by climatic variations. Major gaps of knowledge lie in the area of rumen turnover time of individual plant species and their component parts and quantitative data on the effects of snow and ice on the quantity and quality of available forage. 


\section{ACKNOWLEDGEMENTS}

We thank George Eckalook and Ludi Pudluk for obtaining the caribou and Frank Miller and Anne Gunn for helping with the necropsies. Logistic support was provided by Polar Continental Shelf Project and their Resolute Bay personnel, especially Fred Alt, Eddie Chapman and Bill Presley. We thank Anne Gunn, Michael Kingsley, Ward Stevens, and George Scotter for reviewing this article.Cooperation was received from the Northwest Territories Wildlife Service and the Resolute Bay Council and Hunters and Trappers Association. Dale Vitt identified the mosses.

\section{REFERENCES}

DONEFER, E., CRAMPTON, E.W and LLOYD, L.E. 1960. Prediction of the nutritive value index of a forage from in vitro rumen fermentation data. Journal of Animal Science 19:545-552.

FISCHER, C.A. and DUNCAN, E.A. 1975. Ecological studies of caribou and muskoxen in the Arctic Archipelago and northern Keewatin. Report to Polar Gas Environmental Program by Renewable Resources Consulting Services Limited, Edmonton. 194 p.

JOHNSON, R.R. 1966. Techniques and procedures for in vitro and in vivo rumen studies. Journal of Animal Science 25:855-875.

MILCHUNAS, D.G., DYER, M.I., WALLMO, O.C. and JOHNSON, D.E. 1978. In vivo/in vitro relationships of Colorado mule deer forages. Colorado Division of Wildlife, Special Report No. 43. $44 \mathrm{p}$.

PARKER, G.R. 1978. The diets of muskoxen and Peary Caribou on some islands in the Canadian High Arctic. Canadian Wildlife Service Occasional Paper No. 35. 19 p.

, THOMAS, D.C., BROUGHTON, E. and GRAY, D.R. 1975. Crashes of muskoxen and Peary caribou populations in 1973-74 on the Parry Islands, Arctic Canada. Canadian Wildlife Service Progress Note No. 56. 10 p.

PERSON, S.J., WHITE, R.G. and LUICK, J.R. 1975. In vitro digestibility of forages utilized by Rangifer tarandus. In: Proceedings of the First International Reindeer/Caribou Symposium, Fairbanks, Alaska. 251-256.

PERSON, S.J., PEGAU, R.E., WHITE, R.G. and LUICK, J.R. 1980. In vitro and nylon-bag digestibilities of reindeer and caribou forages. Journal of Wildlife Management 44(3):613-622.

SHANK, C.C., WILKINSON, P.F. and PENNER, D.F. 1978. Diet of Peary caribou, Banks Island, N.W.T. Arctic 31(2):125-132.

THOMAS, D.C., RUSSELL, R.H., BROUGHTON, E. and MADORE, P.L. 1976. Investigations of Peary caribou populations on some Canadian Arctic Islands, March 1975. Canadian Wildlife Service Progress Note No. 64. 13 p.

THOMAS, D.C., RUSSELL, R.H., BROUGHTON, E., EDMONDS, E.J. and GUNN, A. 1977. Further studies of two populations of Peary caribou in the Canadian Arctic. Canadian Wildlife Service Progress Note No. 80.14 p.

THOMAS, D.C., and BROUGHTON, E. 1978. Status of three Canadian caribou populations north of $70^{\circ}$ in winter 1977. Canadian Wildlife Service Progress Note No. 85. $12 \mathrm{p}$.

TILLEY, J.M.A. and TERRY, R.A. 1963. A two-stage technique for in vitro digestion of forage crops. Journal of the British Grasslands Society 18:104-111.

TRUDELL, J., WHITE, R.G., STAALAND, H., EKERN, K., KILDEMO, K., JACOBSEN, E. and GARRE, E. 1979. Comparison of some factors affecting the in vitro digestibility of reindeer forages. Second International Reindeer/Caribou Symposium, Røros, Norway (Abs.).

URNESS, P.J., SMITH, A.D. and WATKINS, R.K. 1977. Comparison of in vivo and in vitro dry-matter digestibility of mule deer forages. Journal of Range Management 30(2):119-121. 